\title{
Thermo-mechanical modelling of arc-trench regions
}

\author{
JILLES VAN DEN BEUKEL and RINUS WORTEL \\ Department of Theoretical Geophysics, Institute of Earth Sciences, University of Utrecht, Budapestlaan 4, \\ 3584 CD Utrecht (The Netherlands)
}

(Received December 8, 1987; revised version received March 10, 1988)

\begin{abstract}
Van den Beukel, J. and Wortel, R., 1988. Thermo-mechanical modelling of arc-trench regions. Tectonophysics, 154:177-193.

The thermal structure of the shallow part of a subduction zone, i.e. the region between the trench and the volcanic line, is calculated with a finite difference method. Published heat flow measurements, in combination with rheological arguments and the distribution of interplate thrust earthquakes, are used to constrain the thermal structure of this region and the magnitude of shear stresses acting on the plate contact. A pressure and temperature dependent rheology is used to model shear stresses. From our thermo-mechanical modelling it follows that temperatures at the plate contact and within the upper plate are determined by the subduction of cold material and by frictional heating. For models that satisfy the constraints the average shear stress at the plate contact (between the trench and the volcanic line) varies from about 10 to about $40 \mathrm{MPa}$ and shear stresses during brittle deformation range from 2.5 to $7.5 \%$ of the lithostatic pressure. For a wide range of convergence velocities $(4-12 \mathrm{~cm} / \mathrm{yr})$ and ages of the subducting oceanic lithosphere (30-150 Ma), shear stresses and temperatures at and above the plate contact are essentially independent of these parameters. Temperatures at the upper surface of the slab for the preferred thermal models are in good agreement with pressure-temperature conditions during high-pressure metamorphism inferred from mineral assemblages in the Franciscan Complex of California. Frictional heating has a large influence on the conditions for high-pressure metamorphism.
\end{abstract}

\section{Introduction}

Processes at convergent plate margins, associated with the subduction of oceanic lithosphere, are important for the evolution of continental crust. High-pressure metamorphic belts are formed in the region near the trench (Oxburgh and Turcotte, 1971; Ernst, 1977). Subduction related volcanism results in the formation of new continental crust (Gill, 1981). It is obvious that the thermal structure of the upper part of a subduction zone has a large influence on these processes.

Here, we present a thermal model for the region between the trench and the volcanic line (arc-trench region; see Fig. 1). Arc-trench re- gions are characterized by a small, gradually increasing dip of the slab and, as can be inferred from heat flow data, by the absence of an asthenospheric wedge between the slab and the surface. Temperatures are relatively low as a consequence of the subduction process. The depth of the upper surface of the slab in this region is less than about $100 \mathrm{~km}$.

Several authors have studied the thermal structure of a subduction zone (e.g. Minear and Toksöz, 1970; Andrews and Sleep, 1974; Anderson et al., 1978, 1980; Hsui and Toksöz, 1979; Honda and Uyeda, 1983; Honda, 1985). These models, which encompass both the subducting and the overriding plate, exhibit large differences in temperature for 
the arc-trench region which are primarily caused by differences in heat production by friction at the upper surface of the subducting slab. Shear stresses at the plate contact vary from zero $\mathrm{MPa}$ (e.g. Honda and Uyeda, 1983) to values over $100 \mathrm{MPa}$ (e.g. Anderson et al., 1978). Constraints on either temperatures or shear stresses are thus essential for the thermal modelling of an arc-trench region. In addition, the dip of the slab in these models is constant and approximately equal to the dip of the slab at great depth, whereas in reality the dip gradually increases until the slab has reached a depth of about $100-200 \mathrm{~km}$. The geometry of the slab in these models is not suitable for a detailed investigation of the thermal structure of an arctrench region.

In this study we use published heat flow data, in combination with rheological arguments and the depth distribution of interplate thrust earthquakes, to infer the thermal structure of an arctrench region and the magnitude of shear stresses acting on the plate contact. A constant curvature, rather than a constant dip, has been employed to model the geometry of the slab, giving a much better approximation of its actual geometry in an arc-trench region.

\section{Description of the model}

Isacks and Barazangi (1977) give the geometry of the upper surface of the descending slab, as inferred from seismicity, for a number of subduction zones. Differences in the geometry of the slab at depths less than $100 \mathrm{~km}$ are small compared to differences at greater depths. The distance between the trench and the volcanic line is typically $175-275 \mathrm{~km}$; the depth of the upper surface of the slab below the volcanic line is typically $90-110$ $\mathrm{km}$.

The geometry of the model is given in Fig. 2. The upper surface of the slab is part of a circle, which gives a reasonable approximation of the actual geometry of the slab in an arc-trench region (Isacks and Barazangi, 1977; Furlong et al., 1982). In the model the dip below the trench is $7^{\circ}$ and the dip below the volcanic line is slightly over $30^{\circ}$. The total distance between the trench and the volcanic line is about $250 \mathrm{~km}$; the depth of the upper surface of the slab below the volcanic line is about $95 \mathrm{~km}$. The geometry of the model is particularly close to that of the subduction zone near northeast Honshu, Japan (Yoshii, 1979). The thickness of the crustal and sedimentary part of

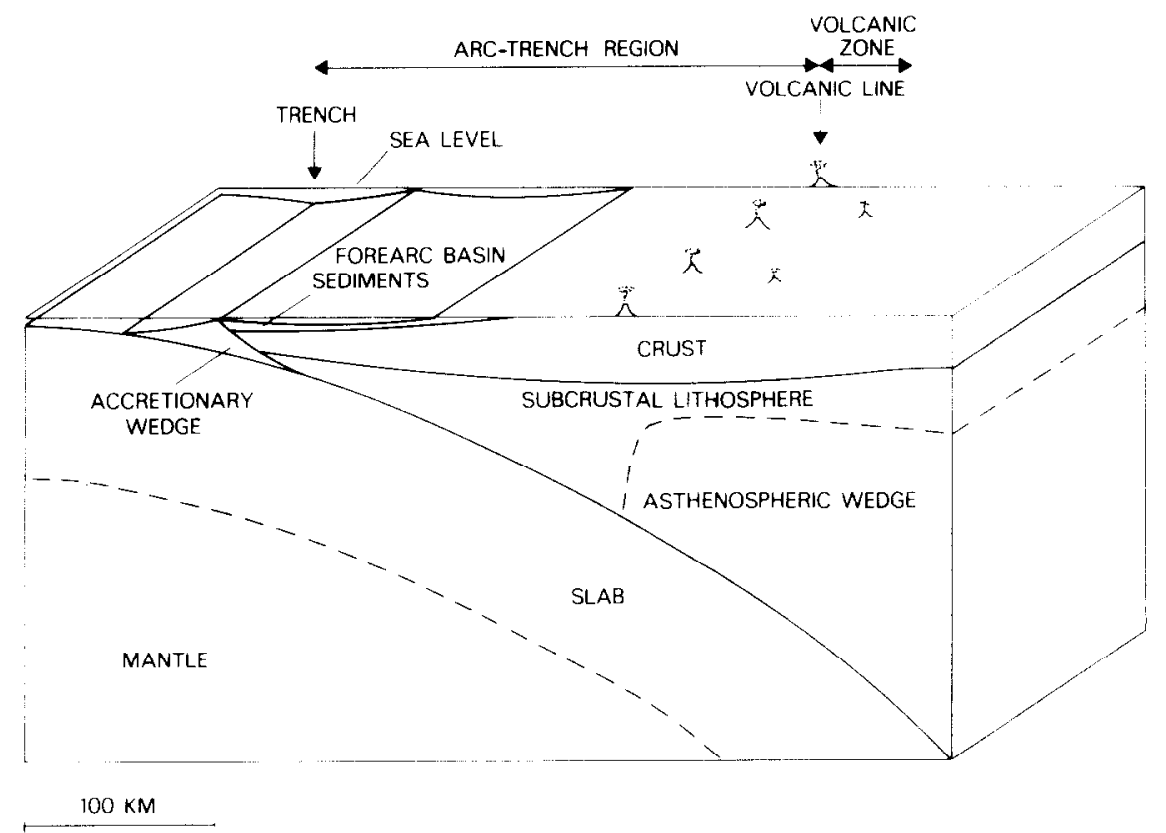

Fig. 1. The shallow part of a subduction zone. Dashed lines indicate the base of the lithosphere, which can only be given schematically. No vertical exaggeration. 


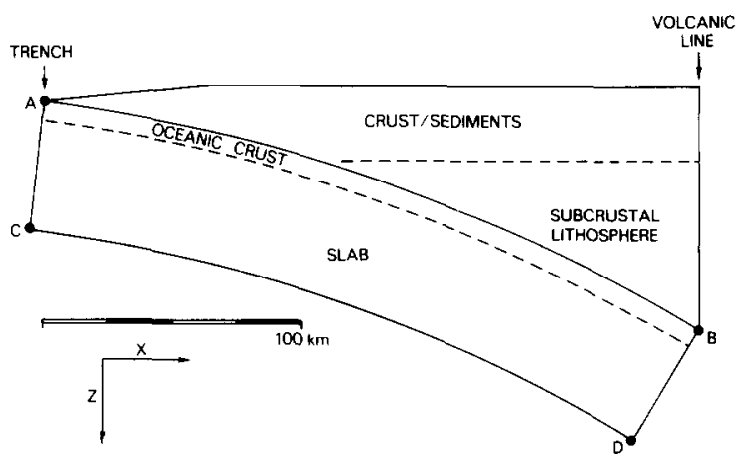

Fig. 2. Geometry of the model.

the upper plate is $25 \mathrm{~km}$ and the thickness of the crust of the slab is $7.5 \mathrm{~km}$. Since we focus here on temperatures at and above the upper surface of the slab, it is sufficient to incorporate only the upper $50 \mathrm{~km}$ of the slab in the model. Within an arc-trench region heating of the slab takes place only in the upper $20-30 \mathrm{~km}$ of the slab.

The time dependent two-dimensional temperature distribution $T(x, z, t)$ (where $z$ is the depth, $x$ the horizontal distance from the trench, $t$ is time and $v$ the velocity; $T$ in ${ }^{\circ} \mathrm{C}$ ) is calculated from:

$\frac{\partial T}{\partial t}+v \cdot \nabla T=\frac{1}{\rho c_{p}}[\nabla \cdot(k \nabla T)+A]$

For crustal material the density $\rho$ is taken to be $2.7 \times 10^{3} \mathrm{~kg} \mathrm{~m}^{-3}$ and the thermal conductivity $k$ is $2.5 \mathrm{~W} \mathrm{~m}^{-1}{ }^{\circ} \mathrm{C}^{-1}$. For subcrustal lithosphere the density is $3.3 \times 10^{3} \mathrm{~kg} \mathrm{~m}^{-3}$ and a temperature dependent thermal conductivity for olivine, from Schatz and Simmons (1972), is used. A value of $1.05 \times 10^{3} \mathrm{~J} \mathrm{~kg}^{-1}{ }^{\circ} \mathrm{C}^{-1}$ has been adopted for the specific heat $c_{\mathrm{p}}$. It can be inferred from heat flow data (see belaw) that the asthenospheric wedge does not extend significantly into the arc-trench region. We have assumed that velocities are zero for material above the slab, thereby neglecting internal deformation in the accretionary wedge (see also below). For the slab itself velocities are equal to the convergence velocity $v_{c}$ between the two plates, except for a small effect due to downbending of the slab. Velocities along circular arcs within the slab (e.g. lines $\mathrm{AB}$ and $\mathrm{CD}$ in Fig. 2) are constant. $A$ is the heat production rate per unit volume due to friction and the decay of radioactive elements. For the slab adiabatic com- pression gives also a small contribution to $A$ (see Minear and Toksöz, 1970).

Finite difference methods are used to solve eqn. (1) numerically. The system of ordinary differential equations which results from the discretization of space variables in the partial differential eqn. (1), is solved with a class of explicit three-step Runge Kutta methods (Van der Houwen, 1977; Verwer, 1977). Gridpoints are located at segments of a circle (e.g. lines $A B$ and $C D$ in Fig. 2) and at straight lines perpendicular to these segments (e.g. lines $\mathrm{AC}$ and $\mathrm{BD}$ ). The distance between gridpoints at these straight lines is $5 \mathrm{~km}$. In order to check the results, calculations have also been made for models with smaller distances between gridpoints. The amount of frictional heat $Q_{\mathrm{f}}$, generated at the upper surface of the descending slab is (per unit time and unit surface of plate contact):

$Q_{\mathrm{f}}=v \tau$

where $v$ is the velocity of the upper surface of the subducting slab, relative to the upper plate, and $\tau$ the shear stress. Shear stresses have been modelled with a pressure and temperature dependent rheology (see below). For gridpoints at the upper surface of the slab the heat production rate by friction $A_{\mathrm{f}}$ (per unit volume) is:

$A_{\mathrm{f}}=\frac{v \tau}{z_{\mathrm{g}}}$

where $z_{\mathrm{g}}$ is the distance between gridpoints at a straight line perpendicular to the plate contact, taken to be equal to the thickness of the shear zone.

Temperatures at the top of the model are assumed to be $0^{\circ} \mathrm{C}$. Temperatures for the downbending oceanic lithosphere below the trench depend on the age of the subducting oceanic lithosphere and are calculated for a boundary layer model (Crough, 1975) with a temperature of $1325^{\circ} \mathrm{C}$ at the base of the lithosphere. At a depth of $50 \mathrm{~km}$ within the slab (line CD in Fig. 2) a constant heat flow, perpendicular to the line CD and equal to the calculated heat flow at point $C$. has been assumed. Temperatures below the volcanic line, at depths less than $80 \mathrm{~km}$, are those of a geotherm with a surface heat flow of $80 \mathrm{~mW}$ $\mathrm{m}^{-2}$. Such a high heat flow is common for the 
volcanic zone and the back-arc region (see also Fig. 3). High temperatures below the volcanic zone can also be inferred from the composition of magmas (Tatsumi et al., 1983) and are likely to be caused by processes within the asthenospheric wedge below the volcanic zone and the back-arc region. Migration of the volcanic line, if any, is slow (Dickinson, 1973) and a high-temperature boundary condition, as defined above, thus seems reasonable. At the start of the model calculations temperatures are those of a geotherm with a surface heat flow of $55 \mathrm{~mW} \mathrm{m^{-2 }}$ and subduction starts instantaneously. Here, we do not focus on the thermal structure of an arc-trench region during the early stages of subduction, but rather on the steady state thermal structure, which has been reached in many subduction zones (see below). A discussion of the mechanisms for the initiation of subduction is given by Cloetingh et al. (1982). During model calculations the geometry of the slab is assumed to be constant.

A substantial part of the heat flow at the surface will be caused by the decay of radioactive elements, concentrated in sediments and crustal material. Thus radiogenic heat production must be incorporated in the thermal models, in order to be able to use heat flow data as a constraint. Generally the following sequence exists in the direction from the trench to the volcanic arc: accretionary wedge-oceanic crust and forearc sediments-arc crust and/or continental crust (Dickinson and Seely, 1979). The heat production rate in crust of oceanic origin is about $0.5 \mu \mathrm{W} \mathrm{m} \mathrm{m}^{-3}$ (Pollack and Chapman, 1977). Crust formed by subduction related volcanism (arc crust) has a low heat production rate of $0.25-0.50 \mu \mathrm{W} \mathrm{m} \mathrm{m}^{-3}$ (Gill, 1981, p. 45). Sediments in the forearc basin, which are derived from arc crust (Dickinson, 1974), are thus also expected to have a low radiogenic heat production. Radiogenic heat production in continental crust, however, is higher: estimates for the average radiogenic heat production rate in continental crust, as given by Weaver and Tarney (1984), range from 0.73 to $0.95 \mu \mathrm{W} \mathrm{m} \mathrm{m}^{-3}$. During the thermal modelling the radiogenic heat production rate in the upper $25 \mathrm{~km}$ of the overriding plate has been varied between a low estimate of $0.4 \mu \mathrm{W}$ $\mathrm{m}^{-3}$ (typical for arc crust and oceanic crust) and a high estimate of $0.9 \mu \mathrm{W} \mathrm{m} \mathrm{m}^{-3}$ (typical for continental crust). Note that the radiogenic heat production rate for offscraped deep-sea sediments, which may form a part of the accretionary wedge, is uncertain and may fall outside of the range 0.4-0.9 $\mu \mathrm{W} \mathrm{m} \mathrm{m}^{-3}$. For the crust of the slab a radiogenic heat production rate has been assumed of $0.5 \mu \mathrm{W}$ $\mathrm{m}^{-3}$.

\section{Constraints on temperatures and shear stresses}

\section{Heat flow}

Heat flow measurements (from Anderson, 1980; Nakamura and Wakita, 1982 and Yoshii, 1983) for the subduction zone near the Japan trench (northeast Honshu) are given in Fig. 3. Heat flow is low in the entire arc-trench region; most data are lower than $40 \mathrm{~mW} \mathrm{~m}^{-2}$. The volcanic line is associated with an increase in heat flow to $75-100$ $\mathrm{mW} \mathrm{m}^{-2}$ over a relatively short distance. The large spread in the heat flow data is attributed to errors in the data and not to real differences in heat flow as a function of distance in the direction parallel to the trench axis. Heat flow data for small segments of this subduction zone, given by Yoshii (1983), show a similar spread. The error for heat flow measurements in arc-trench regions, using ocean probe techniques, is estimated to be about $12 \mathrm{~mW} \mathrm{~m}^{-2}$ (Hyndman, 1976).

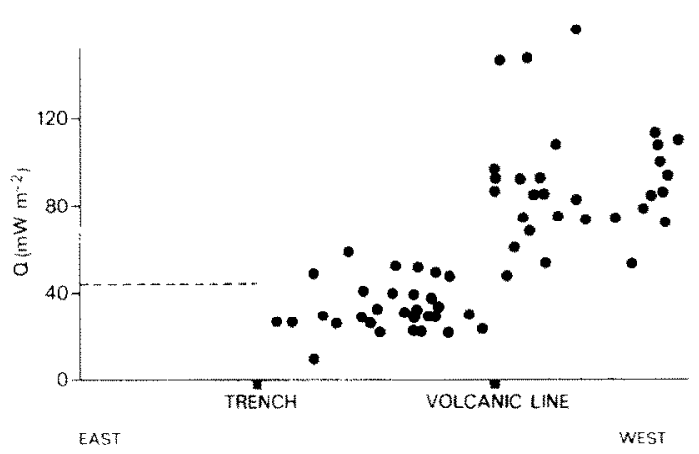

Fig. 3. Heat flow for the subduction zone near the Japan trench (northeast Honshu). Heat flow data from Anderson (1980); Nakamura and Wakita (1982) and Yoshii (1983). The dashed line is the theoretical heat flow (for a boundary layer model from Crough, 1975) for oceanic lithosphere with an age of $120 \mathrm{Ma}$. This is the age of the descending Pacific plate at the Japan trench. The distance between the trench and the volcanic line is about $260 \mathrm{~km}$. 
Other subduction zones show a similar pattern; low heat flow $\left(<40 \mathrm{~mW} \mathrm{~m}^{-2}\right)$ in the arc-trench region and high heat flow in the volcanic zone and the back-arc region (e.g. Watanabe et al., 1977). The increase in heat flow near the volcanic line may be somewhat more gradual than is suggested by the data given in Fig. 3. The low heat flow in the arc-trench region points to temperatures above the slab that are considerably below mantle temperatures. Subduction induced flow of mantle material in the arc-trench region can thus be ruled out. Average values for heat flow data in the central part of the arc-trench region are given in Table 1. The central part of the arc-trench region is defined as the region, where the distance to the trench and the distance to the volcanic line are both greater than $X_{\mathrm{AT}} / 3$ (where $X_{\mathrm{AT}}$ is the distance between the trench and the volcanic line). The heat flow in this part of the arc-trench region will not be influenced by the high temperatures below the volcanic zone (via horizontal conduction) or by processes within the accretionary wedge. Subduction zones with a very large accretionary wedge (Sumatra, Aleutians) may be an exception to this. These subduction zones do not

\section{TABLE 1}

Average values of heat flow data in the central part of the arc-trench region; time since the initiation of subduction

\begin{tabular}{lll}
\hline Subduction zone & $\begin{array}{l}\text { Heat flow } \\
\left(\mathrm{mW} \mathrm{m}{ }^{-2}\right)\end{array}$ & $\begin{array}{l}\text { Duration } \\
\text { (Ma) }\end{array}$ \\
\hline Northeast Honshu & 34 & $>50$ \\
Southwest Honshu & 54 & \pm 15 \\
Cascades & 35 & $>50$ \\
South America & 31 & $>50$
\end{tabular}

a Average values for heat flow data at distances greater than $0.33 \times X_{\mathrm{AT}}$ from the trench and the volcanic line (where $X_{\mathrm{AT}}$ is the total distance between the trench and the volcanic line). Heat flow data from Anderson (1980)-northeast Honshu; Blackwell et al. (1982)-Cascades; Henry (1981)-South America; Hyndman (1976)-Cascades; Nakamura and Wakita (1982)-northeast Honshu; Uyeda and Watanabe (1982)-South America; Watanabe et al. (1977)-southwest Honshu.

buration since the initation of subduction, taken or inferred from Coney and Reynolds (1978)-Cascades; Hilde et al. (1977)-northeast Honshu; Kobayashi (1983) — southwest Honshu; Palacios (1984)_-South America. conform to the adopted geometry (Fig. 2) and are not included in this study. The number of heat flow measurements that have been used to calculate the average values, given in Table 1 , ranges from 9 (South America) to 15 (northeast Honshu). For an error of $12 \mathrm{~mW} \mathrm{~m}^{-2}$ (which is likely to be a high estimate for many of the heat flow data for the Cascades and South America which are inferred from drill hole measurements) these average values are expected to have an error of about 3-4 $\mathrm{mW} \mathrm{m} \mathrm{m}^{-2}$ only.

An average value higher than $40 \mathrm{~mW} \mathrm{~m}^{-2}$ is only obtained for the southwest Honshu subduction zone. The time passed since the initiation of subduction is relatively short for this subduction zone (see Table 1). This may explain the higher heat flow, since it will take time for the lithosphere above the slab to cool, after the initiation of subduction. The other subduction zones have all been active for more than $50 \mathrm{Ma}$. Such a duration of subduction is sufficient for the upper plate to reach a steady state thermal structure (see below). Average values of heat flow data in the central part of the arc-trench region for these subduction zones range from 31 to $35 \mathrm{~mW} \mathrm{~m}^{-2}$. Heat flow profiles and maps for the Central America (Blackwell et al., 1977) and Kuriles (Smirnov and Sugrobov, 1982) subduction zones exhibit a heat flow of about $30 \mathrm{~mW} \mathrm{~m}^{-2}$ in the central part of the arc-trench region. These subduction zones have also been active for more than $50 \mathrm{Ma}$ (Hilde et al., 1977; Karig et al., 1978). For our modelling we have required that, once that a steady state thermal structure has been reached, average heat flow in the central part of the arctrench regions should fall between 30 and $35 \mathrm{~mW}$ $\mathrm{m}^{-2}$.

\section{Rheology}

As follows from rock mechanics experiments the strength of material is determined by pressure, temperature, pore fluid pressure, rock type and strain rate (Kirby, 1983; Tsenn and Carter, 1987). Brittle deformation takes place at lower temperatures whereas plastic deformation dominates at higher temperatures. For brittle deformation the 
shear stress $\tau$ required to cause sliding on a preexisting fault is given by:

$\tau=\mu \sigma_{\mathrm{n}}^{*}$

where $\mu$ is the coefficient of friction and $\sigma_{\mathrm{n}}^{*}$ the effective normal stress, acting on the fault surface:

$\sigma_{\mathrm{n}}^{*}=\sigma_{\mathrm{n}}-P_{\mathrm{f}}$

where $\sigma_{n}$ is the normal stress and $P_{f}$ the pore fluid pressure. For a wide variety of rocks it follows from experimental data that, for $\sigma_{\mathrm{n}}^{*}$ less than 200 $\mathrm{MPa}, \mu$ is approximately equal to 0.85 (Byerlee, 1978). Clays, however, have a much lower coefficient of friction (Bird, 1984). For an arc-trench region the underthrusting of fluid-rich sediments will lead to high pore fluid pressures near the shear zone up to substantial depths (Von Huene, 1984). The exact magnitude of these pore fluid pressures, however, is uncertain. During modelling it has been assumed that, for brittle deformation near the upper surface of the slab, the average shear stress during fault motion increases linearly with the lithostatic pressure $P$ :

$\tau=\gamma P$

Flow laws for plastic deformation that is caused by steady state power law creep have the form (Kirby, 1983):

$\dot{\epsilon}=A_{0}\left(\sigma_{1}-\sigma_{3}\right)^{n} \exp (-Q / R T)$

where $\dot{\epsilon}$ is the strain rate, $T$ the absolute temperature, $R$ the gas constant and $\sigma_{1}$ and $\sigma_{3}$ the maximum and minimum principal stress. $Q, A_{0}$ and $n$ are material constants. The flow law that should be used to model plastic deformation near the upper surface of a descending slab is that of the weakest material near the shear zone. This may be either sedimentary material or oceanic crust (see also Yuen et al., 1978). We have taken a relatively weak limestone rheology as a lower limit for the strength, during plastic deformation, of material at a subduction shear zone. Furthermore, calculations have been made using flow laws for quartzite and diorite (under wet conditions) which are appropriate for material where respectively quartz and feldspar are the dominant minerals, controlling plastic flow. An upper limit for the strength of crustal material, during plastic deformation, at a subduction shear zone is taken to be
TABLE 2

Hlow law parameters

\begin{tabular}{cllll}
\hline Flow law & $\begin{array}{l}A_{0} \\
\left(\mathrm{Kbar}^{-11}\right. \\
\left.\mathrm{s}^{-1}\right)\end{array}$ & $n$ & $\begin{array}{l}Q \\
(\mathrm{kcal} / \\
\text { mole })\end{array}$ & Reference \\
\hline $\begin{array}{l}\text { Limestone } \\
\begin{array}{c}\text { Quartzite } \\
\text { (wet) }\end{array}\end{array}$ & $4.9 \times 10^{7}$ & 2.05 & 50.4 & Schmid (1976) \\
$\begin{array}{c}\text { Diorite } \\
\text { (wet) }\end{array}$ & 80 & 2.44 & 38.2 & $\begin{array}{l}\text { Koch et al. } \\
(1980)\end{array}$ \\
Diabase & $5.2 \times 10^{8}$ & 3.0 & 85 & $\begin{array}{l}\text { Carter (1982) } \\
\text { Caristan (1982) }\end{array}$ \\
\hline
\end{tabular}

given by a flow law for diabase (under dry condjtions). Material constants for flow laws that are used during model calculations are given in Table 2. Note that these laboratory derived flow laws should be regarded as giving an upper bound for the strength of the material under natural conditions. By using several flow laws (and also including a model without any frictional heating), we are able to cope with the difficulties that arise from the uncertainty as to what material determines the strength during ductile deformation at the shear zone and the uncertainty in the extrapolation of laboratory flow laws to geologic strain rates. We do not want to exclude the possibility that a relatively weak limestone or quartzite flow law gives a better approximation of the strength of oceanic crust, during ductile deformation at geologic strain rates, than a diorite or diabase flow law. From our modelling we infer the magnitude of shear stresses at the plate contact, rather than the type of material that determines the strength at the shear zone during ductile deformation.

In order to calculate $\tau\left(-\left(\sigma_{1}-\sigma_{3}\right) / 2\right)$ from eqn. (6), an estimate of $\dot{\epsilon}$ is needed. Yuen et al. (1978) have modelled deformation at shear zones for a number of different rheologies. A typical strain rate that can be inferred from their models is $10^{-12} \mathrm{~s}^{-1}$. Here, $\dot{\epsilon}$ is taken to be $\left(v_{\mathrm{c}} / v_{\text {ref }}\right) \times$ $10^{-12} \mathrm{~s}^{-1}\left(v_{\mathrm{c}}\right.$ in $\left.\mathrm{cm} / \mathrm{yr}\right) \cdot v_{\text {ref }}$ is a reference velocity of $8 \mathrm{~cm} / \mathrm{yr}$. During modelling, shear stresses for a certain place at the plate contact are calculated both for brittle deformation (eqn. 5) and for plastic deformation (eqn. 6). The lowest of these two 
values is used to model heat production by friction (eqn. 2b).

\section{Seismicity}

Near the upper surface of the slab a zone of thrust earthquakes extends from a depth of about $15-20 \mathrm{~km}$ to a depth of about $40 \mathrm{~km}$, occasionally to depths of 60-70 km (Isacks and Molnar, 1971; McCann et al., 1979). Great thrust earthquakes do not rupture the interface between the two plates below a depth of about $40 \mathrm{~km}$ (McCann et al., 1979; Ruff and Kanamori, 1983). At the same depth Sykes and Quittmeyer (1981) locate the transition from principally seismic to principally aseismic motion at the plate contact. This is confirmed by studies of the seismicity for several subduction zones (e.g. Davies and House (1979) for the Aleutians; Isacks et al. (1981) for the New Hebrides; LeFevre and McNally (1985) for Middle America).

For continental fault zones Meissner and Strehlau (1982) have shown that below the seismogenic zone the strength of material is low as a consequence of thermally activated creep. For oceanic lithosphere the absence of intraplate earthquakes below the $700-800^{\circ} \mathrm{C}$ isotherm is consistent with rapid weakening for olivine rheologies at these temperatures (Wiens and Stein, 1983). Reduced strength, due to thermally activated creep, also seems the most likely explanation for principally aseismic motion at a subduction shear zone for depths greater than about $40 \mathrm{~km}$. For our models we have required that the brittle-ductile transition at the plate contact takes place at a depth between 30 and $50 \mathrm{~km}$.

\section{Model calculations}

Parameters for all models are given in Table 3. As a starting point calculations have been made for five models (TA1, TLIM1, TQUA1, TDIO1 and TDIA1). The age of the subducting oceanic lithosphere in these models is $70 \mathrm{Ma}$ and the convergence velocity is $8 \mathrm{~cm} / \mathrm{yr}$. These values are close to the average values of these parameters for present-day subduction zones (Wortel, 1982). The models have a radiogenic heat production rate $A_{\mathrm{r}}$
TABLE 3

Input parameters for model calculations

\begin{tabular}{lllccl}
\hline Model & $\gamma$ & Flow law & $\begin{array}{l}T_{\mathrm{s}}{ }^{\mathrm{a}} \\
(\mathrm{Ma})\end{array}$ & $\begin{array}{l}v_{\mathrm{c}}{ }^{\mathrm{b}} \\
(\mathrm{cm} / \mathrm{yr})\end{array}$ & $\begin{array}{l}A_{\mathrm{r}}{ }^{\mathrm{c}} \\
\left(\mu \mathrm{W} \mathrm{m}{ }^{3}\right)\end{array}$ \\
\hline TA1 & 0. & & 70 & 8 & 0.7 \\
TA2 & 0. & & 70 & 8 & 0.9 \\
TLIM1 & 0.03 & limestone & 70 & 8 & 0.7 \\
TLIM2 & 0.03 & limestone & 70 & 8 & 0.9 \\
TLIM3 & 0.025 & limestone & 70 & 8 & 0.9 \\
TQUA1 & 0.05 & quartzite & 70 & 8 & 0.7 \\
TQUA2 & 0.05 & quartzite & 70 & 4 & 0.7 \\
TQUA3 & 0.05 & quartzite & 70 & 12 & 0.7 \\
TQUA4 & 0.05 & quartzite & 30 & 8 & 0.7 \\
TQUA5 & 0.05 & quartzite & 150 & 8 & 0.7 \\
TDIO1 & 0.09 & diorite & 70 & 8 & 0.7 \\
TDIO2 & 0.09 & diorite & 70 & 8 & 0.4 \\
TDIO3 & 0.075 & diorite & 70 & 8 & 0.4 \\
TDIA1 & 0.11 & diabase & 70 & 8 & 0.7 \\
TDIA2 & 0.11 & diabase & 70 & 8 & 0.4 \\
\hline
\end{tabular}

${ }^{a}$ Age of the oceanic lithosphere at the trench.

${ }^{b}$ Convergence velocity between the two plates.

c Radiogenic heat production rate in the upper $25 \mathrm{~km}$ of the upper plate.

within the crustal and sedimentary part of the upper plate of $0.7 \mu \mathrm{W} \mathrm{m}^{-3}$. Model TA1 is a model without heat production by friction. Shear stresses for plastic deformation for the other models are determined by flow laws for limestone, quartzite, diorite and diabase. For these models values for $\gamma$, which determines the shear stress (and thus heat production by friction) for brittle deformation, are chosen in such a way that the transition from brittle to plastic deformation at the shear zone takes place at a depth of approximately $40 \mathrm{~km}$ (thus satisfying the depth constraint for the brittle-ductile transition at the plate contact).

At a time $50 \mathrm{Ma}$ after the initiation of subduction a steady state thermal structure has been reached completely (see Fig. 4a). All results of model calculations will be given for a steady state situation $50 \mathrm{Ma}$ after the initiation of subduction. The heat flow for the models TA1-TDIA1, 50 Ma after the initiation of subduction, is given in Fig. 4b. The models exhibit a low heat flow in the arc-trench region, which is the result of the advection of cold material. It is clear that frictional heating at the plate contact has a large influence on the magnitude of this low. Average heat flow in 

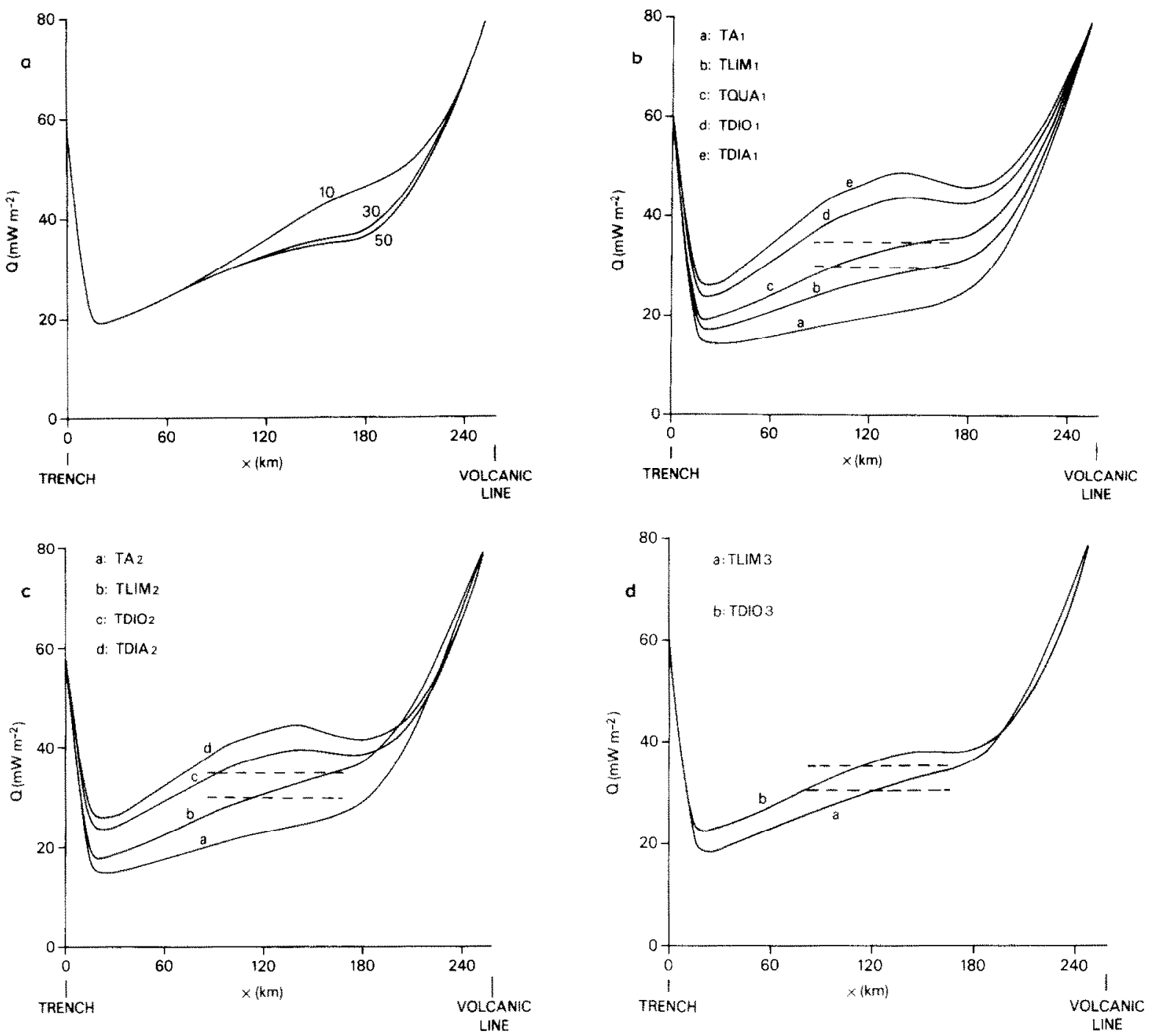

Fig, 4. a. Heat flow, 10, 30 and $50 \mathrm{Ma}$ after the initiation of subduction for model TQUA1. b. Heat flow, 50 Ma after the initiation of subduction. Dashed lines give the interval for the average heat flow, inferred from heat flow data, in the central part of the arc-trench region for subduction zones, where subduction started more than $50 \mathrm{Ma}$ ago. c. Heat flow, $50 \mathrm{Ma}$ after the initiation of subduction, for models TA2, TLIM2, TDIO2 and TDIA2. d. Heat flow, $50 \mathrm{Ma}$ after the initiation of subduction, for models TLIM3 and TDIO3.

the central part of the arc-trench region varies from less than $20 \mathrm{~mW} \mathrm{~m}^{-2}$ for model TA1 to about $45 \mathrm{~mW} \mathrm{~m}^{-2}$ for model TDIA1. Only the model with a flow law for quartzite has an average heat flow in the central part of an arc-trench region that falls within the interval of $30-35 \mathrm{~mW}$ $\mathrm{m}^{-2}$ inferred from heat flow data.

Model calculations have also been made for models similar to the models TA1-TDIA1, but with a different radiogenic heat production rate $A_{\mathrm{r}}$ in the crustal part of the upper plate. Variations in $A_{\mathrm{r}}$ have a much greater influence on temperatures near the surface than on temperatures at the plate contact. The heat flow for the models TA2, TLIM2 (with a high estimate for $A_{\mathrm{r}}$ of $0.9 \mu \mathrm{W} \mathrm{m} \mathrm{m}^{-3}$ ), TDIO2 and TDIA2 (with a low estimate of 0.4 $\mu \mathrm{W} \mathrm{m}^{-3}$ ) are given in Fig. $4 \mathrm{c}$. Of these models, model TLIM2 meets both the constraint on heat flow and that on the depth of the brittle-ductile transition. Model TDIO2 exhibits a heat flow that 
is slightly too high. Models similar to model TDIO2, but with a lower value for $\gamma$ (between 0.05 and 0.075 ) are acceptable, however.

A large number of model calculations have been made for different flow laws, and different values for $A_{\mathrm{r}}$ and $\gamma$. It was found that the constraints on heat flow and the depth of the brittle-ductile transition could not be satisfied for models with a flow law for a diabase. Models without heat production by friction could not meet the heat flow constraint. Acceptable models,
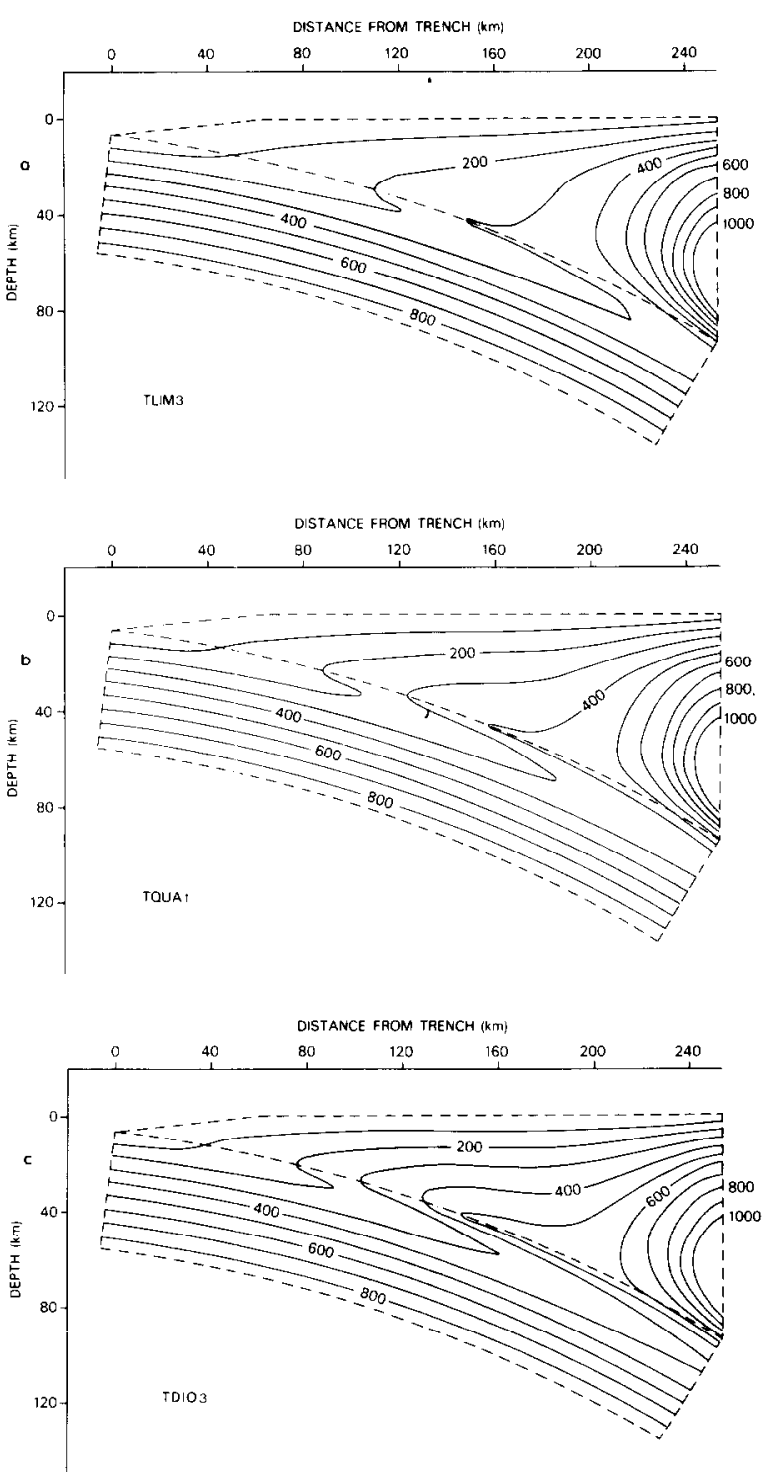

Fig. 5. Temperature distributions for models TLIM3 (a), TQUA1 (b) and TDIO3 (c), $50 \mathrm{Ma}$ after the initiation of subduction. with a limestone, quartzite or diorite rheology to model plastic deformation, exhibit a brittle-ductile transition between 30 and $50 \mathrm{~km}$ and shear stresses for brittle deformation between 2.5 and $7.5 \%$ of the lithostatic pressure ( $\gamma$ between 0.025 and 0.075 ). For a given flow law, a lower value for $\gamma$ leads to a brittle-ductile transition at greater depth. Temperature distributions for the models TLIM3, TQUA1 and TDIO3 are given in Fig. 5. Of all acceptable models, the models TLIM 3 and TDIO3 exhibit the lowest and highest temperatures respectively. These two models also give a lower and upper bound for the magnitude of shear stresses at the plate contact. Temperatures and shear stresses at the plate contact, as a function of depth, are given in Fig. 6 .

Calculations have been made for models with a quartzite flow law and convergence velocities of 4 and $12 \mathrm{~cm} / \mathrm{yr}$. Most of the subduction zones have convergence velocities between these two values. The influence of velocities on the thermal structure turns out to be very small (see Fig. 7a). The effect of an increased cooling, due to the faster subduction, approximately cancels the effect of an increased heat production by friction. Figure $7 \mathrm{~b}$ shows temperatures at the plate contact for two models similar to model TQUA1, but with a young (30 Ma) and a very old (150 Ma) subducting oceanic lithosphere. The influence of the age of the oceanic lithosphere on the thermal structure is greater than that of the convergence velocity. Differences between models for which the age of the subducting plate varies are small, however, compared to the differences between the models TLIM3, TQUA1 and TDIO3. Acceptable models with an age of the subducting plate of 30 or 150 Ma show a very similar range in temperatures and shear stresses as the models TLIM3 and TDIO3.

From our thermo-mechanical modelling it can be concluded that temperatures at and above the plate contact in an arc-trench region are mainly determined by the way the upper part of the slab heats up, during its descent, as a consequence of frictional heating. About $85-90 \%$ of the frictional heat generated at the plate contact is used to heat up downgoing material in the upper part of the slab and only a small fraction contributes to the surface heat flow. Unless subduction takes place 

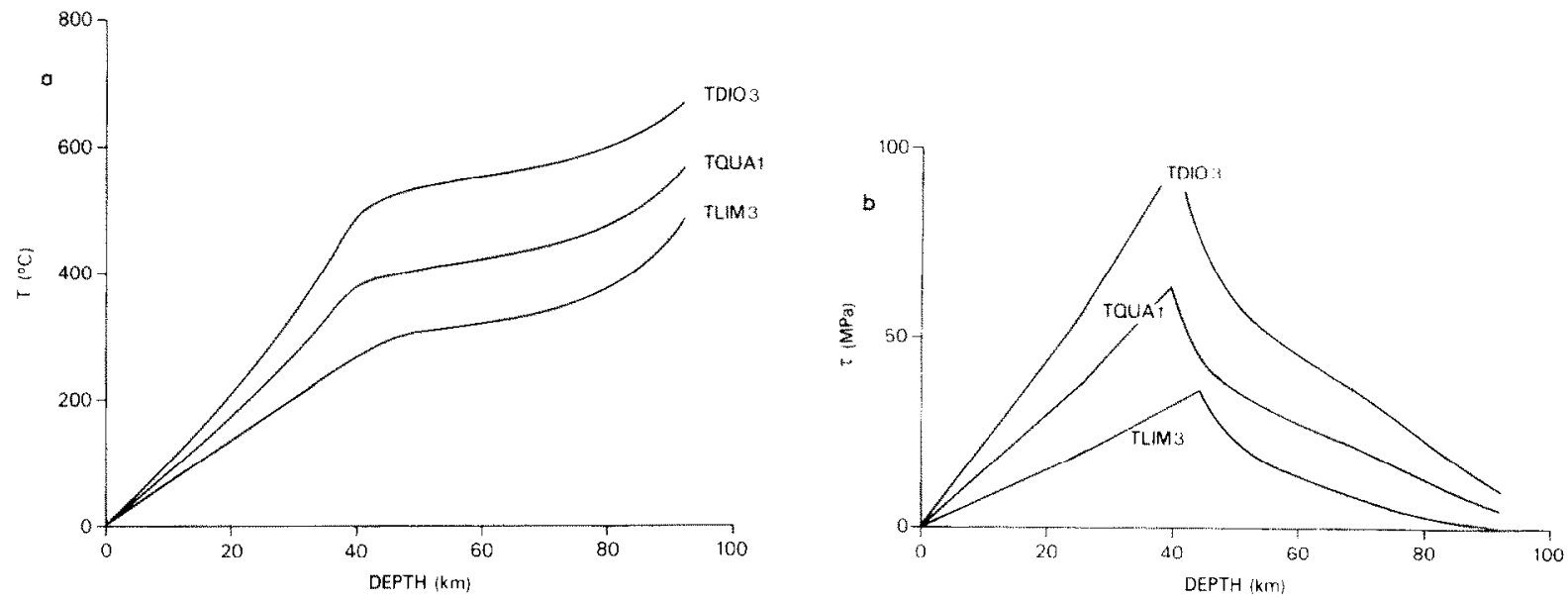

Fig. 6. a. Temperatures at the upper surface of the slab (line AB in Fig. 2), $50 \mathrm{Ma}$ after the initiation of subduction, for models TLIM3, TQUA1 and TDIO3. b. Shear stresses at the upper surface of the slab, 50 Ma after the initiation of subduction, for models TLIM3, TQUA1 and TDIO3.

of very young oceanic lithosphere or with a very low convergence velocity, the age of the subducting lithosphere and the convergence velocity will not have a large influence on the temperatures at and above the plate contact. During brittle deformation, friction causes heating up to temperatures which enable plastic flow to take place. At depths greater than that of the brittle-ductile transition friction only leads to a small increase of temperature with depth at the plate contact. $A$ low level of interplate seismicity may exist at depths of about $40-80 \mathrm{~km}$, since shear stresses for plastic deformation do not fall off rapidly to values near zero. Average shear stresses at the plate contact (between points $A$ and $B$ in Fig. 2) are $12 \mathrm{MPa}$

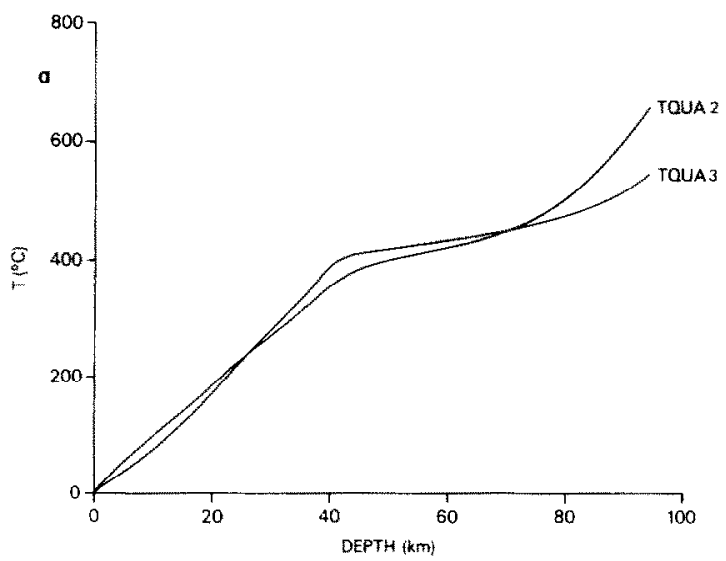

(model TLIM3), $24 \mathrm{MPa}$ (model TQUA1) and 38 MPa (model TDIO3). These values are primarily determined by the flow law that is used to model plastic deformation and are, for a wide range of convergence velocities (4-12 cm/yr) and ages of the subducting oceanic plate $(30-150 \mathrm{Ma})$, essentially independent of these parameters. Average shear stresses for the models TQUA2-TQUA5 range from 21 to $26 \mathrm{MPa}$.

\section{High-pressure metamorphism}

Subduction of oceanic lithosphere can lead to the formation of an accretionary wedge, which consists of sedimentary material. In a high-pres-

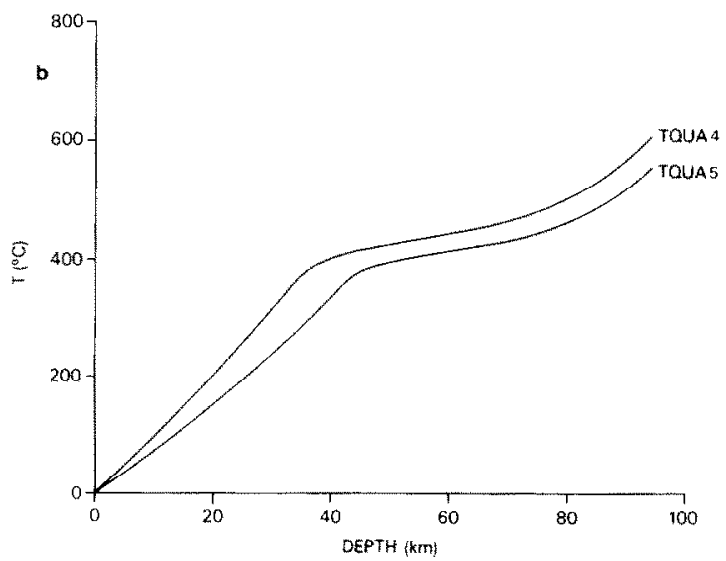

Fig. 7. a. Temperatures at the upper surface of the slab, $50 \mathrm{Ma}$ after initiation of subduction, for models TQUA2 and TQUA3. b. Temperatures at the upper surface of the slab, $50 \mathrm{Ma}$ after the initiation of subduction, for models TQUA4 and TQUA5. 
sure metamorphic belt, such as the Franciscan Complex of California, material that was once part of an accretionary wedge and situated at substantial depths (up to about $40 \mathrm{~km}$ ) is now exposed at the surface. High-pressure metamorphic belts are characterized by mineral assemblages that form at relatively low temperatures, which are generally thought to be related to the low temperatures that exist in the upper part of a subduction zone (e.g. Oxburgh and Turcotte, 1971). An increase in both metamorphic grade and radiometric ages exists in the direction from the former trench to the former volcanic arc (e.g. Ernst, 1977).

From observed mineral assemblages and experimentally determined or calculated phase equilibria estimates can be made of the pressuretemperature conditions to which the material in a high-pressure metamorphic belt has been subjected. Since sedimentary material in downward movement is expected to be close to the upper surface of the descending slab, $P-T$ conditions during prograde metamorphism will give an estimate of the conditions at the upper surface of the slab during metamorphism. It must be kept in mind, however, that the $P-T$ conditions inferred from mineral assemblages need not always represent a steady state thermal structure (as our model temperatures do) but may also represent relatively high temperatures shortly after the initiation of subduction.

Figure 8 gives $P-T$ conditions for material from the Franciscan Complex. For zones A to D the grade of metamorphism increases, whereas the volume of material, now exposed, decreases (Coleman and Lee, 1963). Zone D represents high-grade blueschist blocks (some meters in extent), which have been emplaced tectonically into lower grade metamorphic material of regional extent (zone A to $\mathrm{C}$ ). Zone $\mathrm{E}$ represents material that has been metamorphosed at relatively high temperatures in contact with peridotite (Brown et al., 1982).

Radiometric ages for zones $\mathrm{D}$ and $\mathrm{E}$ span a relatively small time range of about 140 to $160 \mathrm{Ma}$ (Brown et al., 1982; Cloos, 1985). These ages are close to the age of $155-165 \mathrm{Ma}$ for the Coast Range Ophiolite (Hopson et al., 1981) and indicate that metamorphism took place during, or

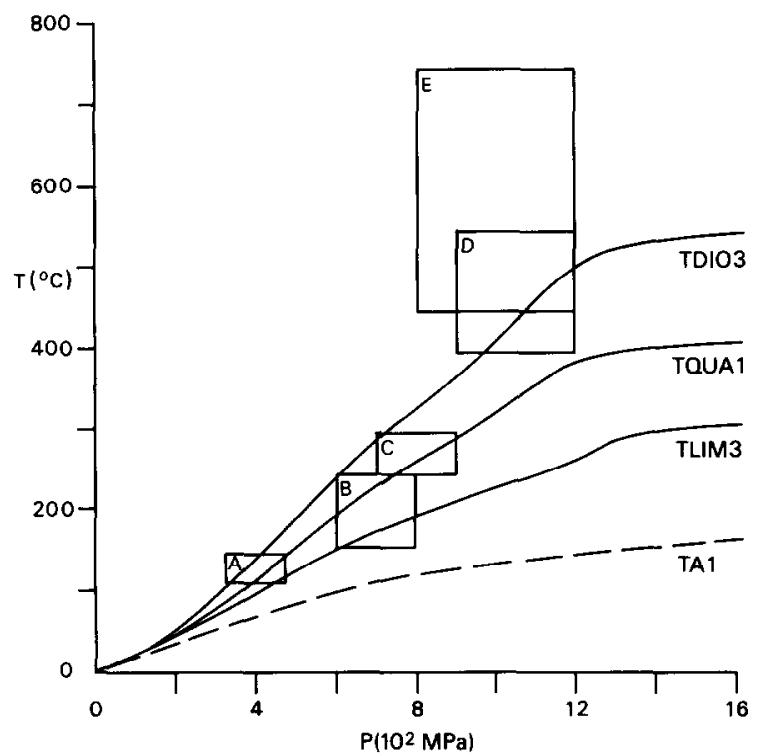

Fig. 8. Temperatures at the upper surface of the descending slab, as a function of pressure, for models TA1, TLIM3, TQUA1 and TDIO3. Temperatures $5 \mathrm{~km}$ above the upper surface of the slab differ less than $25^{\circ} \mathrm{C}$. Zones A to $\mathrm{E}$ represent $P-T$ conditions during metamorphism for material in the Franciscan Complex, California. Zone A: Franciscan material at Diablo Range (Bostick, 1974). Zone B: Franciscan blueschist facies metasedimentary material from Diablo Range (Moore and Liou, 1979). Zone C: Franciscan blueschist facies material from northern California Coast Ranges (Black Butte and Ball Rock areas) and Panoche Pass region (Brown and Ghent, 1983). Zone D: High-grade blueschist blocks, generally metabasalts, emplaced tectonically into a melange of lower-grade Franciscan material (Taylor and Coleman, 1968; Brown and Bradshaw, 1979; Moore, 1984). Zone E: Amphibolite and barroisite schists, metamorphosed in contact with peridotite, from Shuksan Metamorphic Suite (Brown et al., 1982). All estimates for temperatures are based on mineral parageneses, except for zone A where temperatures are inferred from the maturation of organic material

shortly after, the initiation of the subduction episode that led to the formation of the Franciscan. Radiometric ages for zones $\mathrm{B}$ and $\mathrm{C}$ range from about 70 to $150 \mathrm{Ma}$, a time range similar to that for Franciscan fossils (Suppe and Armstrong, 1972; Cloos, 1985). This greater time range and the regional extent of the metamorphic rocks from zones $\mathrm{A}$ to $\mathrm{C}$ indicate that the $P-T$ conditions for zones $\mathrm{A}$ to $\mathrm{C}$ represent a steady state thermal situation. Note that, although it takes about 30 Ma for an arc-trench region as a whole to reach a steady state thermal structure, temperatures at the plate contact do so within a few million years and 
temperatures within the upper plate, where its thickness is less than $30 \mathrm{~km}$, do so within about 10 Ma (see Fig. 4a).

Figure 8 also gives temperatures at the upper surface of the descending slab for the models TA1, TLIM3 and TDIO3. Models TLIM3 and TDIO3 provide a lower and an upper limit for temperatures in an arc-trench region. Thermal models in which heat production by friction is not included or very low (model TAl in Fig. 8; see also Wang and Shi, 1984) give temperatures that are considerably lower than the temperatures for zones $\mathrm{A}$ to C. Such models can only give temperatures in agreement with $P-T$ conditions for zones A to $\mathrm{C}$ if subduction takes place with a very low velocity of about $1 \mathrm{~cm} / \mathrm{yr}$ or less (Wang and Shi, 1984). No present-day subduction zone has a subduction rate near $1 \mathrm{~cm} / \mathrm{yr}$ and it seems unlikely that subduction of oceanic lithosphere with such low velocities has been widespread in the past. On the other hand, the range of $P-T$ conditions for the preferred thermal models (TLIM3, TQUA1 and TDIO3) turns out to be in very good agreement with $P-T$ conditions for metamorphic rocks from zone A to $C$. The good agreement between $P-T$ conditions for these rocks, likely to be the result of a steady state thermal situation, and our preferred models is an additional support for our modelling. As is the case for temperatures in an arc-trench region as a whole, temperatures in the accretionary wedge and $P-T$ conditions for high-pressure metamorphism are heavily influenced by frictional heating near the upper surface of the slab and thus by pore fluid pressures and the rheological properties of material near the shear zone.

Temperatures for material from zone $E$ are considerably higher than model temperatures. Metamorphism took place in contact with peridotite and Brown et al. (1982) have proposed that these higher temperatures are caused by hot ultramafic material within the hanging wall during the initiation of subduction. Similar high-temperature metamorphic rocks have been found directly below well-preserved ophiolites (e.g. Ghent and Stout, 1981). The radiometric ages and the basaltic composition of the high-grade tectonic blocks (zone D) suggest that they have been sheared-off from the subducting oceanic plate shortly after the initiation of subduction. Possibly their $P-T$ conditions represent an early phase of subduction when temperatures at the plate contact were already determined by the rheological properties of material at the plate contact, but may have been somewhat higher than the temperatures during later phases, due to a lesser amount of weakening (see also Pavlis, 1986).

Within an accretionary wedge uplift may take place as a consequence of underplating and deepseated movements of low-strength sediments (Cloos, 1982; Moore et al., 1982; Silver et al., 1985). We expect that upward velocities of sediments will be very small compared to the convergence velocity between the two plates. Firstly, it takes at least 20-30 $\mathrm{Ma}$ for blueschists to reach the surface (Ernst, 1972). Secondly, observed uplift rates of accretionary complexes are only a few tenths of a mm/yr (Pavlis and Bruhn, 1983). Calculations have been made for models similar to model TQUA1 but with an upward velocity (in the direction perpendicular to the upper surface of the slab) within the upper plate. Although movements within an accretionary wedge will certainly exhibit a much more complex pattern, such models can give an estimate of the influence of possible large scale movements of sediments. Differences in temperature between a model with an upward velocity of $0.3 \mathrm{~mm} / \mathrm{yr}$ within the upper plate and model TQUA1 are less than $5^{\circ} \mathrm{C}$ at the upper surface of the slab and less than $20^{\circ} \mathrm{C}$ within the part of the upper plate where the slab is at depths less than $30 \mathrm{~km}$. Even for a model with a velocity within the upper plate that is as high as 3 $\mathrm{mm} / \mathrm{yr}$, temperatures at the upper surface of the slab differ less than $20^{\circ} \mathrm{C}$ everywhere. Thus even if significant movements of sediments in an accretionary wedge occur, conditions for high-pressure metamorphism will still be primarily determined by the way the upper part of the slab heats up as a result of frictional heating.

\section{Discussion}

The first step of the process that leads to subduction related volcanism is melting of material in the crust of the slab or in the asthenospheric wedge (e.g. Wyllie, 1979; Gill, 1981). In both cases 
high temperatures in the asthenospheric wedge above the slab are required for melting. From heat flow data we have inferred that the asthenospheric wedge does not extend significantly into the arctrench region. The asthenospheric wedge does exist, however, below the back-arc region (as follows from the high heat flow data in this region) and below the volcanic zone (as follows from the composition of arc-basalt magmas; Tatsumi et al., 1983). Thus the volcanic line and the boundary of the asthenospheric wedge approximately coincide. We think it likely that the location of the volcanic line is determined by the extent of the asthenospheric wedge and that the part of the arc-trench region near the volcanic line is a transition zone, where equilibrium exists between cooling (caused by the nearby cold slab) and heating (caused by the nearby asthenospheric wedge). The absence of earthquakes in this region (the aseismic zone from Yoshii, 1979) can be attributed to higher temperatures in material that is still part of the lithosphere. During subduction, the volcanic line may slowly migrate, with a velocity less than $1 \mathrm{~km} / \mathrm{Ma}$ (Dickinson, 1973). Because the thermal relaxation time of the upper plate in an arc-trench region is relatively short (see Fig. 4b), this will not have a large influence on the overall thermal structure of an arc-trench region.

Endothermic dehydration reactions for watercontaining minerals in the crust of the descending slab start at a depth of about $75 \mathrm{~km}$ (Delany and Helgeson, 1978). The influence of these reactions on the thermal structure of an arc-trench region will be limited to temperatures in the upper part of the slab below this depth. The heat needed for the reactions will be readily supplied by the nearby asthenospheric wedge.

Frictional heating during brittle deformation depends on the pore fluid pressure and the coefficient of friction of material near the shear zone. For accretionary wedges, observed pore fluid pressures range from about $67.5 \%$ to nearly $100 \%$ of the lithostatic pressure (Davis et al., 1983). Chu et al. (1981) and Bird (1984) give values of 0.2-0.3 for the coefficient of friction for clays or clayey fault gouges. Shear stresses within clay-rich material at the base of an accretionary wedge, subjected to the observed range of pore fluid pressures, will range from $0 \%$ to about $10 \%$ of the lithostatic pressure (eqn. 3; see also Davis et al., 1983), corresponding to values of $\gamma$ between 0 and 0.1 . This agrecs well with the interval for $\gamma$ of 0.025 (model TLIM3) to 0.075 (model TDIO3) for the preferred thermal models. During thermal modelling $\gamma$ is assumed to be independent of depth, whereas in reality $\gamma$ may vary (Zhao et al., 1986). Values for $\gamma$ in our thermal models should be seen as average values over the brittle part of the shear zone. In addition, it should be noted that the sharp peak of the shear stress near the brittle-ductile transition (see Fig. 6b) is a simplification. In reality this transition will be more gradual (e.g. Kirby, 1983).

From theoretical considerations on mantle convection McKenzie and Jarvis (1980) infer that the average shear stress at the plate contact in an arc-trench region is unlikely to exceed $50 \mathrm{MPa}$. On the base of a force balance Bird (1978) has made estimates of the average shear stress at the plate contact at depths less than $100 \mathrm{~km}$ for two subduction zones where back-arc spreading occurs. The estimates are $16.5 \pm 7.5 \mathrm{MPa}$ for the Mariana and $22 \pm 10 \mathrm{MPa}$ for the Tonga subduction zone. These values are in good agreement with the average shear stress between the trench and the volcanic line of the models TLIM3 (12MPa) and TQUA1 $(24 \mathrm{MPa})$. The average shear stress for model TDIO3 is higher $(38 \mathrm{MPa})$.

In spite of the relatively low strength of material at the plate contact (compared to the strength of material within a plate), frictional heating does have a large influence on the thermal structure of an arc-trench region. For shear stresses during brittle deformation that are about $5 \%$ of the lithostatic pressure, frictional heating at strike-slip faults, such as the San Andreas fault, would lead to a very small heat flow anomaly, that would probably go undetected (Lachenbruch and Sass, 1980). The greater influence of frictional heating on the thermal structure of an arc-trench region is caused by the continuous advection of cold material, which leads to relatively low temperatures in an arc-trench region and thus, for a given pressure and temperature dependent rheology for material at the plate contact, to relatively high shear stresses. For an arc-trench region the depth 
to which frictional heating occurs is much greater than for a strike-slip fault and, for a given rheology for material at the plate contact, the average shear stress will be higher.

The total resistive force (per unit-length of trench), caused by friction in the upper part of a subduction zone, can be obtained by integrating shear stresses over the total down-dip length of the plate contact. This resistive force ranges from about $3 \times 10^{12} \mathrm{~N} / \mathrm{m}$ (model TLIM3) to $10 \times 10^{12}$ $\mathrm{N} / \mathrm{m}$ (model TDIO3). Estimates of the gravitational forces that drive the plates (ridge push and slab pull forces), as given by Wortel and Cloetingh (1983), are of the same order of magnitude. This indicates that this resistive force can be of major importance for intraplate stress fields and plate kinematics.

\section{Conclusions}

(1) From published heat flow data it can be inferred that, for older subduction zones (where subduction started more than $50 \mathrm{Ma}$ ago), the average heat flow in the central part of the arctrench region is $30-35 \mathrm{~mW} \mathrm{~m}^{-2}$.

(2) From our thermo-mechanical modelling it follows that shear stresses at the upper surface of the descending slab are relatively low. The average shear stress between the trench and the volcanic line lies between 10 and $40 \mathrm{MPa}$. During brittle deformation, shear stresses are about $2.5-7.5 \%$ of the lithostatic pressure. Despite these low shear stresses, frictional heating has a large influence on temperatures near the plate contact and within the upper plate in an arc-trench region. For a wide range of convergence velocities $(4-12 \mathrm{~cm} / \mathrm{yr})$ and ages of the subducting oceanic lithosphere (30-150 $\mathrm{Ma}$, temperatures and shear stresses are essentially independent of these parameters.

(3) Temperatures at the upper surface of the slab, for models that are in agreement with heat flow data and for which a steady state thermal structure has been reached, are in good agreement with $P-T$ conditions for high-pressure metamorphism inferred from mineral assemblages in the Franciscan Complex of California. Conditions for high-pressure metamorphism are heavily in- fluenced by frictional heating, and thus by pore fluid pressures and the rheological properties of material near the shear zone.

\section{Acknowledgements}

We would like to thank Dr. Sierd Cloetingh and Prof. N.J. Vlaar for many helpful discussions. Jilles van den Beukel is supported by a research grant from Royal Dutch/Shell.

\section{References}

Anderson, R.N., 1980. 1980 Update of heat flow in the East and Southeast Asian seas. In: D.E. Hayes (Editor), The Tectonic and Geologic Evolution of Southeast Asian Seas and Islands. Geophys. Monogr., Am. Geophys. Union, 23: $319-326$

Anderson. R.N., Delong, S.E. and Schwarz, W.M., 1978. Thermal model for subduction with dehydration in the downgoing slab. J. Geol., 86: 731-739

Anderson, R.N., DeLong, S.E. and Schwarz, W.M., 1980. Dehydration, asthenospheric convection and seismicity in subduction zones. J, Geol., 88: 445-451.

Andrews, D.J. and Sleep, N.H., 1974. Numerical modelling of tectonic flow behind island ares. Geophys. J. R. Astron Soc., 38: 237-251

Bird, P., 1978. Stress and temperature in subduction shear zones. Geophys. J.R. Astron. Soc., 55: 411-434.

Bird, P., 1984. Hydration-phase diagrams and friction of montmorillonite under laboratory and geologic conditions, with implications for shale compaction, slope stability and strength of fault gouge. Tectonophysics, 107: 235-260.

Blackwell, D.D., Ziagos, J. and Mooser, F., 1977. Heat flow and the thermal effects of subduction in southern Mexico. Eos, Trans. Am. Geophys, Union, 58: 1233.

Blackwell, D.D., Bowen, R.G., Hull, D.A., Riccio, J. and Steele, J.L., 1982. Heat flow, arc volcanism, and subduction in northern Oregon. I. Geophys. Res, 87: 8735-8754

Bostick, N.H. 1974. Phytoclasts as indicators of thermal metamorphism, Franciscan assemblage and Great Valley sequence (upper Mesozoic), California. Geol. Soc. Am., Spec. Pap.. 153: $1-17$

Brown, F.H. and Bradshaw. J.Y.. 1979. Phase relations of pyroxene and amphibole in greenstone, blueschist and eclogite of the Franciscan complex, California. Contrib. Mineral. Petrol., 71: 67-83.

Brown, E.H. and Ghent, E.D., 1983. Mineralogy and phase relations in the blueschist facies of the Black Butte and Ball Rock areas, northern California Coast Ranges. Am. Mineral., 68: 365-372.

Brown, E.H., Wilson, D.L. Armstrong, R.L. and Harakal, J.E., 1982. Petrologic, structural, and age relations of serpentinite, amphibolite, and blueschist in the Shuksan Suite of the Iron Mountain-Gee Point area, North Cascades, Washington. Geol. Soc. Am., Bull.. 93: 1087-1098. 
Byerlee, J.D., 1978. Friction of rocks. Pure Appl. Geophys., 116: 615-626.

Caristan, Y., 1982. The transition from high-temperature creep to fracture in Maryland diabase. J. Geophys. Res., 87: $6781-6798$.

Chu, C.L., Wang, C.Y. and Lin, W., 1981. Permeability and frictional properties of San Andreas fault gouge. Geophys. Res. Lett., 8: 565-568.

Cloetingh, S.A.P.L., Wortel, M.J.R. and Vlaar, N.J., 1982. Evolution of passive continental margins and initiation of subduction zones. Nature, 297: 139-142.

Cloos, M., 1982. Flow melanges: numerical modeling and geologic constraints on their origin in the Franciscan subduction complex, California. Geol. Soc. Am. Bull., 93: $330-345$.

Cloos, M., 1985. Thermal evolution of convergent plate margins: thermal modeling and reevaluation of isotopic Ar-ages for blueschists in the Franciscan complex of California. Tectonics, 4: 421-434.

Coleman, R.G. and Lee, D.E., 1963. Glaucophane-bearing metamorphic rock types of the Cazadero area, California. J. Petrol., 4: 260-301.

Coney, P.J. and Reynolds, S.J., 1978. Overview of Mesozoic-Cenozoic Cordilleran plate tectonics. In: R.B. Smith and G.P. Eaton (Editors), Cenozoic Tectonics and Regional Geophysics of the Western Cordillera. Geol. Soc. Am., Mem., 152: 51-92.

Crough, S.T., 1975. Thermal model of oceanic lithosphere. Nature, 256: 388-390.

Davies, J. and House, L., 1979. Aleutian subduction zone seismicity, volcano-trench separation and their relation to great thrust-type earthquakes. J. Geophys. Res., 84: 4583-4591.

Davis, D., Suppe, J. and Dahlen, F.A., 1983. Mechanics of fold-and-thrust belts and accretionary wedges. J. Geophys. Res., 88: 1153-1172.

Delany, J.M. and Helgeson, H.C., 1978. Calculation of the thermodynamic consequences of dehydration in subducting oceanic crust to $100 \mathrm{kbar}$ and $800^{\circ} \mathrm{C}$. Am. J. Sci., 278: 638-686.

Dickinson, W.R., 1973. Widths of modern arc-trench gaps proportional to past duration of igneous activity in associated magmatic arcs. J. Geophys. Res., 78: 3376-3389.

Dickinson, W.R., 1974. Sedimentation within and beside ancient and modern magmatic arcs. In: R.H. Dott and R.H. Shaver (Editors), Modern and Ancient Geosynclinal Sedimentation. Soc. Econ. Paleontol. Mineral., Spec. Publ., 19: 230-239.

Dickinson, W.R. and Seely, D.R., 1979. Structure and stratigraphy of forearc regions. Am. Assoc. Pet. Geol. Bull., 63: 2-31.

Frnst, W.G., 1972. Occurrence and mineralogic evolution of blueschist belts with time. Am J. Sci., 272: 657-668.

Ernst, W.G., 1977. Mineral parageneses and plate tectonic settings of relatively high-pressure blueschist belts. Fortschr. Mineral., 54: 192-222.
Furlong, K.P., Chapman, D.S. and Alfeld, P.W., 1982. Thermal modeling of the geometry of subduction with implications for the tectonics of the overriding plate. J. Geophys. Res., 87: $1786-1802$.

Ghent, E.D. and Stout, M.Z., 1981. Metamorphism at the base of the Semail ophiolite. J. Geophys. Res., 86: 2557-2571.

Gill, J., 1981. Orogenic Andesites and Plate Tectonics. Springer, Berlin, 390 pp.

Hansen, F.D. and Carter, N.L., 1982. Creep of selected crustal rocks at $1000 \mathrm{MPa}$. Eos, Trans. Am. Geophys. Union, 63: 437.

Henry, S.G., 1981. Terrestrial heat flow overlying the Andean subduction zone. Ph. D. Thesis, Univ. of Michigan, Ann Arbor, Mich., 194 pp.

Hilde, T.W.C., Uyeda, S. and Kroenke, L., 1977. Evolution of the western Pacific and its margin. Tectonophysics, 38: $145-165$.

Honda, S., 1985. Thermal structure beneath Tohoku, Northeast Japan. A case study for understanding the detailed thermal structure of the subduction zone. Tectonophysics, 112: 69-102.

Honda, S. and Uyeda, S., 1983. Thermal process in subduction zones, a review and preliminary approach on the origin of arc volcanism. In: D. Shimozura and I. Yokoyama (Editors), Arc Volcanism: Physics and Tectonics. Terra Scientific Publishing, Tokyo, pp. 117-140.

Hopson, C.A., Mattinson, J.M. and Pessango, E.A., 1981. Coast Range ophiolite, western California. In: W.G. Ernst (Editor), The Geotectonic Development of California. Prentice Hall, New York, N.Y., pp. 418-510.

Hsui, A.T. and Toksöz, M.N., 1979. The evolution of thermal structures beneath a subduction zone. Tectonophysics, 60: $43-60$.

Hyndman, R.D., 1976. Heat flow measurements in the inlets of southwestern British Columbia. J. Geophys. Res., 81: 337-349.

Isacks, B.L. and Barazangi, M., 1977. Geometry of Benioff zones: lateral segmentation and downwards bending of subducted lithosphere. In: M. Talwani and W.C. Pitman, III (Editors), Island Arcs, Deep Sea Trenches and Back-Arc Basins. Am. Geophys. Union, Washington, D.C., pp. 99-114.

Isacks, B.L. and Molnar, P., 1971. Distribution of stresses in the descending lithosphere from a global survey of focal mechanism solutions of mantle earthquakes. Rev. Geophys. Space Phys., 9: 103-174.

Isacks, B.L., Cardwell, R.K., Chatelain, J.L., Barazangi, M., Marthelot, J.M., Chinn, D. and Louat, R., 1981. Seismicity and tectonics of the central New Hebrides island arc. In: D.W. Simpson and P.G. Richards (Editors), Earthquake Prediction, an International Review. Am. Geophys. Union, Washington, D.C., pp. 93-116.

Karig, D.E., Caldwell, R.K., Moore, G.F. and Moore, D.G., 1978. Late Cenozoic subduction and continental-margin truncation along the northern Middle America trench. Geol. Soc. Am. Bull., 89: 265-276. 
Kirby, S.H, 1983. Rheology of the lithosphere. Rev. Geophys Space Phys., 21: 1458-1487.

Kobayashi, K., 1983. Fore-arc volcanism and cycles of subduction. In: D. Shimozura and I. Yokoyama (Editors), Arc Volcanism: Physics and Tectonics. Terra Scientific Publishing, Tokyo, pp. 153-163.

Koch, P.S., Christie, J.M. and George, R.P., 1980. Flow law of "wet" quartzite in the $\alpha$-quartz field. Eos, Trans. Am. Geophys. Union, 61: 376

Lachenbruch, A.H. and Sass, J.H., 1980. Heat flow and energetics of the San Andreas fault system. J. Geophys. Res., 85: $6185-6222$.

LeFevre, L.V. and McNally, K.C., 1985. Stress distribution and subduction of aseismic ridges in the Middle America subduction zone. J. Geophys. Res., 90: 4495-4510.

McCann, W.R., Nishenko, S.P., Sykes, L.R. and Krause, J., 1979. Seismic gaps and plate tectonics: seismic potential for major boundaries. Pure Appl. Geophys., 117: 1082-1147.

McKenzie, D. and Jarvis, G., 1980. The conversion of heat into mechanical work by mantle convection. J. Geophys. Res.. 85: 6093-6096.

Meissner, R. and Strehlau, J, 1982. Limits of stresses in continental crust and their relation to the depth-frequency distribution of shallow earthquakes. Tectonics. 1: 73-89.

Minear, J.W. and Toksöz, M.N., 1970. Thermal regime of a downgoing slab and new global tectonics. J. Geophys. Res. 75: $1397-1419$.

Moore, D.E., 1984. Metamorphic history of a high-grade blueschist exotic block from the Franciscan complex, California. J. Petrol., 25:126-150.

Moore, D.E. and Liou, J.G., 1979. Mineral chemistry of some Franciscan blueschist facies metasedimentary rocks from the Diablo Range, California. Geol. Soc. Am., Bull., 90: 1089-1091.

Moore, J.C., Watkins, J.S. and Shipley, T.H., 1982. Summary of accretionary processes, deep sea drilling project leg 66: offscraping, underplating, and deformation of the slope apron. In: Initial Reports of the Deep Sea Drilling Project, Vol. 66. U.S. Government Printing Office, Washington, D.C., pp. 825-836.

Nakamura, Y. and Wakita, H., 1982. Terrestrial heat flow around the aseismic front of the Japanese island arc. Tectonophysics, 81: T25-T36.

Oxburgh, E.R. and Turcotte, D.L., 1971. Origin of paired metamorphic belts and crustal dilation in island are regions. J. Geophys. Res., 76: 1315-1327.

Palacios, C.M., 1984. Considerations about the plate tectonic model, volcanism and continental crust in the southern part of the central Andes. Tectonophysics, 106: 205-214.

Pavlis, T.L., 1986. The role of strain heating in the evolution of megathrusts. J. Geophys. Res., 91: 12407-12422.

Pavlis. T.L. and Bruhn, R.L., 1983. Deep-seated flow as a mechanism for the uplift of broad forearc ridges and its role in the exposure of high $P / T$ metamorphic terranes. Tectonics, 2: 473-497.

Pollack, H.N. and Chapman, D.S., 1977. On the regional variation of heat flow, geotherms, and lithospheric thickness. Tectonophysics, 38: 279-296.

Ruff, L. and Kanamori, H., 1983. Seismic coupling and uncoupling at subduction zones. Tectonophysics, 99: 99-117.

Schatz, J.F. and Simmons, G., 1972. Thermal conductivity of earth materials at high temperatures. J. Geophys. Res., 77: 6966-6983

Schmid, S.M., 1976. Rheological evidence for changes in the deformation mechanism of Solenhofen limestone towards low stresses. Tectonophysics, 31: T21-T28.

Silver, E.A., Ellis, M.J., Breen, N.A. and Shipley, T.H., 1985. Comments on the growth of accretionary wedges. Geology, 13: $6-9$.

Smirnov, Y. and Sugrobov, V.M., 1982. Terrestrial heat flow in the northwestern Pacific. Tectonophysics, 83: 109-122.

Suppe, J. and Armstrong, R.L., 1972. Potassium-argon dating of Franciscan metamorphic rocks. Am. J. Sci., 272:217-233.

Sykes, L.R. and Quittmeyer, R.C., 1981. Repeat times of great earthquakes along simple plate boundaries. In: D.W. Simpson and P.G. Richards (Editors), Earthquake Prediction, an International Review. Am. Geophys. Union, Washington, D.C., pp. $217-247$.

Tatsumi, Y., Sakuyama, M, Fukuyama, H. and Kushiro, I. 1983. Generation of arc basalt magmas and thermal structure of the mantle wedge in subduction zones. J. Geophys. Res., 88: 5815-5825.

Taylor, H.P. and Coleman, R.G., $1968,{ }^{18} \mathrm{O} /{ }^{16} \mathrm{O}$ ratios of coexisting minerals in glaucophane-bearing metamorphic rocks. Geol. Soc. Am. Bull., 79: 1727-1755.

Tsenn, M.C. and Carter, N.L., 1987. Upper limits of power law creep of rocks. Tectonophysics, 136: 1-26.

Uyeda, S. and Watanabe, T., 1982. Terrestrial heat flow in western South America. Tectonophysics, 83: 63-70.

Van der Houwen, P.J., 1977. Construction of integration formulas for initial value problems. North-Holland, Amsterdam, $269 \mathrm{pp}$.

Verwer, I.G., 1977. A class of stahilized three-step Runge Kutta methods for the numerical integration of parabolic equations. J. Comp. Appl. Math., 3: 155-166.

Von Huene, R., 1984. Tectonic processes along the front of modern convergent margins. Ann. Rev. Earth Planet. Sci. 12: $359-381$.

Wang, C.Y. and Shi, Y.L., 1984. On the thermal structure of subduction complexes; a preliminary study. J. Geophys. Res., 89: 7709-7718.

Watanabe, T., Langseth, M.G. and Anderson, R.N., 1977. Heat flow in back-are basins of the western Pacific. In: $M$. Talwani and W.C. Pitman. III (Editors), Island Arcs, Deep Sea Trenches and Back-Arc Basins. Am. Geophys. Union, Washington, D.C.. pp. 137-160.

Weaver, B.L. and Tarney, J., 1984. Empirical approach to estimating the composition of the continental crust. Nature, 310: $575-577$.

Wiens, D.A. and Stein, S., 1983. Age dependence of oceanic intraplate seismicity and implications for lithospherio evolution. J. Geophys. Res., 88: 6455-6468. 
Wortel, R., 1982. Seismicity and rheology of subducted slabs. Nature, 296: 553-556.

Wortel, R. and Cloetingh, S., 1983. A mechanism for fragmentation of oceanic plates. In: J.S. Watkins and C.L. Drake (Editors), Studies in Continental Margin Geology. Am. Assoc. Pet. Geol., Mem., 34: 793-801.

Wyllie, P.J,, 1979. Magmas and volatile components. Am. Mineral., 64: 469-500.

Yoshii, T., 1979. A detailed cross section of the deep seismic zone beneath Northeast Honshu, Japan. Tectonophysics, 55: $349-360$.

Yoshii, T., 1983. Cross sections of some geophysical data around the Japanese islands. In: T.W.C. Hilde and S. Uyeda (Editors), Geodynamics of the Western Pacific-Indonesian region. Am. Geophys. Union, Washington, D.C., pp. 343-354.

Yuen, D.A., Fleitout, L., Schubert, G. and Froidevaux, C., 1978. Shear deformation zones along major transform faults and subducting slabs. Geophys. J.R. Astron. Soc., 54: 93-119.

Zhao, W.L., Davis, D.M., Dahlen, F.A. and Suppe, J., 1986. Origin of convex accretionary wedges: evidence from Barbados. J. Geophys. Res., 91: 10246-10258. 